\title{
PEMBERIAN PROBIOTIK TERHADAP PENINGKATAN KADAR KALSIUM DARAH PADA PASIEN PENYAKIT GINJAL KRONIK TERMINAL
}

\section{The Effect of Probiotic on The Blood Calcium on The Increase of Calcium Levels in Patients with Terminal Chronic Renal Disease}

\author{
Taufik Maryusman ${ }^{1}$, Ari Yulistianingsih ${ }^{1}$, M. Sulchan ${ }^{1}$, Shofa Chasani ${ }^{2}$ \\ 1Program Studi IImu Gizi, Fakultas Kedokteran Universitas Diponegoro Semarang \\ ${ }^{2}$ Bagian Penyakit Dalam, Fakultas Kedokteran Universitas Diponegoro, RS Kariadi Semarang \\ E-mail: pembelajartaufik@gmail.com
}

\begin{abstract}
ABTRACT
Patients with Terminal Chronic Renal Disease (ESRD) generally have impaired metabolism of minerals such as calcium. Probiotics can increase the balance of gastrointestinal microflora. Suplementation probiotics may increase levels of calcium. The aim of this study was to analyze the effect of probiotics on the increase of calcium levels. This study used a true experiment research using a randomized pre-post test control group design involving 24 subjects divided into 2 groups at random. The treatment group was given lactobacillus probiotics $\left(4.0 \times 10^{\circ} \mathrm{CFU}\right)$ each day in capsul, while the control group was given standard treatment. Statistical analyzes applied paired t-test and independent t-test. Data regarding characteristics of subject were collected using a structured questionnaire. Calcium levels measured by CPO methods and It conducted before intervension and after the intervention. Calcium levels in the treatment group increased at $0.9 \mathrm{~g} / \mathrm{dl}$, or higher than in the control group $0.7 \mathrm{~g} / \mathrm{dl}$. The treatment group showed a significant increase of calcium level $(p=0.02)$. But, this increases did not make a significant difference between the 2 groups. Giving of probiotics increases blood calcium levels even in a small level, therefore it is beneficial to be given to patients with ESRD.
\end{abstract}

Keywords: lactobacillus probiotics, calcium levels, ESRD

\section{ABSTRAK}

Penderita Penyakit Ginjal Kronik (PGK) terminal pada umumnya mengalami gangguan metabolisme mineral seperti kalsium. Probiotik mampu meningkatkan keseimbangan mikroflora saluran pencernaan. Suplementasi probiotik mampu meningkatkan kadar kalsium. Tujuan penelitian ini adalah menganalisis pengaruh pemberian probiotik terhadap kadar kalsium darah pada pasien PGK terminal. Penelitian ini merupakan penelitian true experiment dengan rancangan randomized pre-post test control group design yang melibatkan 24 subjek yang dibagi menjadi 2 kelompok secara acak. Kelompok perlakuan diberikan probiotik lactobacillus $\left(4.0 \times 10^{\circ} \mathrm{CFU}\right)$ per hari dalam bentuk kapsul, sedangkan kelompok kontrol diberikan pengobatan standar. Pengumpulan data penelitian meliputi karakteristik subjek yang dilakukan dengan wawancara menggunakan kuesioner. Data kalsium darah diperoleh dari hasil pemeriksaan dengan metode OCP. Analisis statistik yang dilakukan adalah uji paired $t$-tes dan independent $t$-test. Kadar kalsium pada kelompok perlakuan meningkat $0,9 \mathrm{~g} / \mathrm{dl}$, atau lebih tinggi dibandingkan pada kelompok kontrol $0,7 \mathrm{~g} / \mathrm{dl}$. Kelompok perlakuan menunjukan peningkatan kadar kalsium secara bermakna $(p=0,02)$. Namun kenaikan ini tidak memberikan perbedaan yang bermakna antara dua kelompok $(p=0,21)$ Pemberian probiotik meningkatkan kadar kalsium darah walapun tidak banyak, sehingga bermanfaat untuk diberikan kepada pasien PGK terminal.

Kata kunci: probiotik lactobacillus, kadar kalsium, PGK terminal 


\section{PENDAHULUAN}

$\mathrm{P}$ enderita Penyakit Ginjal Kronik (PGK) meningkat setiap tahunnya. ${ }^{1}$ Penderita PGK terminal untuk mempertahankan hidupnya memerlukan pengganti fungsi ginjal yang tetap berupa Hemodialisis (HD). ${ }^{2}$ Penderita PGK terminal sering ditemukan dengan kondisi hipokalsemia akibat penurunan absorbsi kalsium melalui usus. ${ }^{3}$ Pembentukan metabolit vitamin $D$ yang aktif merupakan penyebab utama gangguan absorbsi kalsium. Selain itu, kekurangan hormon paratiroid dan Vitamin $D$ aktif menyebabkan kekurangan kalsium. ${ }^{4} \quad$ Kalsium merupakan salah satu mineral esensial yang memiliki peran penting dalam proses fisiologis, yang meliputi kontraksi otot rangka, otot polos dan mengontrol fungsi vital sel. Kesetimbangan kalsium pada orang dewasa dalam sirkulasi dan ekstraseluler dipertahankan pada nilai 2,2-2,6 mmol/L. ${ }^{5}$ Kesetimbangan ini akan terganggu oleh perubahan konsentrasi albumin plasma dan abnormalitas protein yang diakibatkan oleh PGK sehingga sering terjadi hipokalsemia. 3,6 The National Kidney Foundation Kidney Disease Outcome Quality Initiative atau biasa disebut NKF K/DOQI melaporkan adanya hubungan antara kadar serum kalsium yang rendah dengan meningkatnya angka kematian pada pasien PGK yang menjalani $H D$ dan menyimpulkan bahwa ada gangguan metabolisme mineral yang juga nantinya berdampak pada penyakit jantung iskemi dan gagal jantung. ${ }^{7}$

Penderita PGK terminal selain menjalani hemodialisis juga memerlukan perbaikan pada beberapa indikator penting lainnya seperti memperbaiki metabolisme mineral secara optimal dan meningkatkan penyerapan zat gizi. Perubahan positif pada indikator tersebut sangat ditentukan oleh terapi konservatif yang diberikan secara tepat baik melalui pengobatan, pemberian makanan tambahan dan makanan fungsional. 3,8

Probiotik merupakan salah satu jenis makanan fungsional yang mampu meningkatkan metabolisme dan penyerapan zat gizi di lumen usus. ${ }^{9}$ Probiotik dari jenis Lactobacillus banyak digunakan karena bakteri ini lebih stabil dan stabilitasnya selama penyimpanan lebih terjamin dibanding dengan jenis bakteri lainnya. ${ }^{10}$ Probiotik Spesies Lactobacillus helveticus memiliki aktivitas enzim spesifik seperti CEPs, cinnamoyl esterase dan $\beta$-glucosidase yang secara tidak langsung dapat menguntungkan manusia dengan meningkatkan bioavaibilitas zat gizi. ${ }^{11}$ Spesies lainnya yaitu Lactobacillus rhamnosus mampu bertahan hidup dengan kondisi yang sangat asam dalam saluran cerna sehingga membantu meingkatkan sistem kekebalan tubuh manusia. ${ }^{12}$

Perkembangan teknologi saat ini, probiotik banyak dikemas dalam bentuk kapsul untuk memudahkan dikonsumsi. Salah satu probiotik dalam bentuk kapsul adalah Lacidofil ${ }^{\mathrm{TM}}$ yang berasal dari spesies Lactobacillus helveticus Rossell -52 sebanyak 0,1 × $10^{9}$ CFU dan Lactobacillus rhamnosus Rosell -11 sebanyak $1,9 \times 10^{9} \mathrm{CFU}$ dengan total bakteri sebanyak $2,0 \times 10^{9}$ (2 milyar) CFU. ${ }^{13,14}$ Penelitian yang dilakukan oleh Ranganatan et al (2013) pemberian probiotik Renady $\mathrm{T}^{\mathrm{TM}}$ dengan beberapa dosis $\left(90 \times 10^{9} \mathrm{CFU}, 180 \times 10^{9} \mathrm{CFU}\right.$, dan $270 \times 10^{\circ} \mathrm{CFU}$ ) dinyatakan aman dan dapat ditoleransi dengan baik oleh pasien PGK stadium akhir. ${ }^{15}$ Kadar probiotik dalam sediaan kapsul Lacidofil ${ }^{\mathrm{TM}}$ yang berisi bakteri sebanyak $2,0 \times 10^{9} \mathrm{CFU}$ yang diberikan sebanyak 2 kapsul per hari merupakan dosis yang sesuai dan dalam batas toleransi aman.

Sampai saat ini belum pernah dilaporkan penelitian mengenai pengaruh probiotik jenis Lactobacillus terhadap kadar kalsium darah. Peneliti tertarik untuk menganalisis pengaruh probiotik Lactobacillus terhadap peningkatan kadar kalsium darah pasien PGK Terminal.

\section{METODE}

Penelitian ini merupakan penelitian true eksperiment dengan rancangan randomized pre-post test control group design. Rancangan ini melibatkan 2 kelompok yaitu kelompok kontrol dan kelompok perlakuan.

Besar sampel berdasarkan rumus perhitungan sampel minimal, sebagai berikut:

$n=2 \sigma^{2}(Z 1-\alpha / 2+Z 1-\beta)^{2}$

$$
\left(\mu_{1}-\mu_{2}\right)^{2}
$$

Keterangan ${ }^{8}: n=$ jumlah sampel tiap kelompok; $\sigma=$ standar deviasi selisih kadar fosfor $(=0,2)$; 
$\mathrm{Z} 1 / 2 \mathrm{\alpha}=$ tingkat kepercayaan 95\% $(1,96) ; \mathrm{Z1}-\beta=$ power test $90 \%(1,28) ; \mu_{1}=$ rata-rata kadar fosfor sebelum intervensi $=6,7 ; \mu_{2}=$ rata-rata kadar fosfor setelah intervensi $=7,0$.

Dengan kemungkinan terjadinya drop out pada sampel, maka disiapkan cadangan sampel sebesar 20\% dari jumlah sampel minimal. Jumlah sampel yang diperlukan untuk setiap kelompok adalah 13 orang maka jumlah untuk 2 kelompok adalah 26 orang. Subjek penelitian ini kemudian dibagi menjadi kelompok perlakuan (13 subjek) dan kelompok kontrol (13 subjek). Ada 2 Subjek mengalami drop out dikarenakan 1 subjek perlakuan menjalani opname selama 5 hari sehingga tidak dapat mengkonsumsi probiotik dan 1 subjek kontrol meninggal dunia saat penelitian. Jumlah yang diteliti menjadi 24 subjek hingga akhir penelitian. Kelompok perlakuan diberikan probiotik lactobacillus $(2 \mathrm{x}$ $10^{9} \mathrm{CFU}$ sebanyak 2 kapsul) dan kelompok kontrol menjalankan HD seperti biasa sebagai terapi standar. Selain itu antara kelompok perlakuan dan kelompok kontrol diberikan obat kalsium karbonat Sebelum dan sesudah intervensi selama 21 hari, subjek dari 2 kelompok tersebut akan diukur kadar kalsium darah dengan cara dan metode yang sama. Penelitian ini dilakukan selama 21 hari berdasarkan pertimbangan atas keefektifan peningkatan kadar kalsium darah dan kelangsungan hidup Lactobacillus spp dalam saluran cerna.

Penelitian dialakukan di unit HD RS Rumah Sehat Terpadu Dompet Dhuafa Bogor, Jawa Barat dan waktu penelitian antara bulan Februari - Maret 2017. Kriteria inklusi subjek antara lain 1) pasien PGK stadium akhir yang menjalani HD > 3 bulan, 2) pasien laki-laki atau perempuan berusia 18-60 tahun, 3) pasien memiliki status gizi baik yang diukur dengan antropometri. Kriteria eksklusi antara lain 1) pasien yang terkena HIVIAIDS, 2) pasien mengkonsumsi obat immunosuppressant dan imunomodullator, 3) pasien mengalami demam tinggi. Kriteria drop out yaitu pasien meninggal atau masuk ICU.

Probiotik dalam penelitian ini berasal suplemen lacidofil ${ }^{\mathrm{TM}}$ dari spesies Lactobacillus helveticus Rossell -52 sebanyak 0,1 x $10^{9} \mathrm{CFU}$ dan Lactobacillus rhamnosus Rosell -11 sebanyak 1,9 $\times 10^{9} \mathrm{CFU}$ dalam bentuk tablet. Keamanan produk lacidofil ${ }^{\mathrm{TM}}$ pernah diujikan oleh Evic-Tox yang bertujuan untuk menguji toksisitas Lacidofil ${ }^{\top M}$ pada tikus SpragueDawley menunjukkan bahwa tidak ada efek toksik yang dihasilkan oleh Lacidofil ${ }^{\mathrm{TM}}{ }^{16}$ Lacidofil $^{\mathrm{TM}}$ dipasarkan sebagai suplemen makanan atau produk farmasetikal dalam bentuk bubuk dalam kapsul atau sachet. Berdasarkan penelitian klinis pada manusia menunjukkan peran Lacidofil $^{T M}$ dalam keseimbangan mikroflora usus dan kesehatan saluran cerna. Strain bakteri yang terdapat dalam Lacidofil ${ }^{\mathrm{TM}}$ terbukti aman serta mampu bertahan terhadap keadaan asam lambung, keadaan basa pada duodenum, dan tingginya kadar asam empedu. Selain itu, probiotik Lacidofil $^{\mathrm{TM}}$ tidak memiliki gen resisten antibiotik. ${ }^{17}$ Lacidofil ${ }^{\top \mathrm{TM}}$ di Indonesia merupakan sediaan probiotik yang memenuhi standar FAO/WHO 2002, yaitu mengandung bakteri hidup yang dapat menyeimbangkan flora usus, jumlahnya adekuat, dan terintegrasi di amerika utara serta eropa berdasarkan penelitian klinis. ${ }^{18,19}$

Data karakteristik dan riwayat penyakit sampel diperoleh dari kuesioner serta rekam medis pasien.

Data Kadar kalsium darah diukur dengan metode CPO yang dilakukan sebelum dan sesudah intervensi pada kelompok perlakuan dan kelompok kontrol. Pemeriksaan ini dilakukan oleh tenaga analis kimia di laboratorium klinik CITO cabang bogor yang telah tersertifikasi international (ISO 9001: 2008).

Analisis data univariat digambarkan dengan means \pm standard deviation. Uji beda dilakukan sebelum dan sesudah intervensi menggunakan Paired t-test. Untuk uji beda antara kelompok perlakuan dengan kelompok kontrol dilakukan Independent t-test.Tingkat kemaknaan penelitian ini adalah pada interval kepercayaan $95 \%$.

Penelitian ini telah mendapat persetujuan dari Komite Etik Fakultas Kedokteran Universitas Diponegoro (No.149/EC/FKRSDK/IV/2017). Informed consent tertulis diperoleh dari subjek penelitian.

\section{HASIL}

\section{Karakteristik subjek di Awal Penelitian}

Penelitian ini melibatkan subjek penelitian sejumlah 24 orang yang memenuhi kriteria 
sampel. Gambaran karakteristik subjek di awal penelitian dapat dilihat pada Tabel 1

Berdasarkan Tabel 1 dibawah ini, sebagian besar subjek berjenis kelamin laki-laki $7(58,3 \%)$ pada kelompok perlakuan dan 7 (58.3\%) juga berjenis kelamin perempuan pada kelompok kontrol. Rerata usia subjek pada kelompok perlakuan 44,17 tahun dan pada kelompok kontrol 48,67 tahun. Sebagian besar subjek memiliki riwayat penyakit hipertensi 10 (83.3\%) pada kelompok perlakuan dan 5 $(41.7 \%)$ pada kelompok kontrol. Subjek dalam penelitian ini sebagian besar menjalani HD selama 4-12 bulan 8 (66.7\%) pada kelompok perlakuan dan $9(75 \%)$ pada kelompok kontrol. Status gizi subjek sebagian besar memiliki status gizi normal 6 (50\%) pada kelompok perlakuan dan 7 (58.3\%) pada kelompok kontrol.

Tabel 1

Deskripsi Karakteristik Subjek di Awal Penelitian

\begin{tabular}{lcc}
\hline \multicolumn{1}{c}{ Karakter } & $\begin{array}{c}\text { Kelompok perlakuan } \\
(\mathrm{n}=12)\end{array}$ & $\begin{array}{c}\text { Kelompok kontrol } \\
(\mathrm{n}=12)\end{array}$ \\
\hline Jenis kelamin & & \\
Laki-laki & $7(58,3 \%)$ & $5(41,7 \%)$ \\
Perempuan & $5(41,7 \%)$ & $7(58,3 \%)$ \\
Umur (tahun) & $44,2 \pm 11,5$ & $48,7 \pm 9,7$ \\
Riwayat penyakit & & \\
Diabetes & $1(8,3 \%)$ & $5(41,7 \%)$ \\
Hipertensi & $10(83,3 \%)$ & $5(41,7 \%)$ \\
Jantung & 0 & $1(8,3 \%)$ \\
Asma & $1(8,3 \%)$ & $1(8,3 \%)$ \\
Lama hemodialisis (bulan) & & \\
$4-12$ & $8(66,7 \%)$ & $9(75 \%)$ \\
$13-24$ & $1(8,3 \%)$ & $2(16,7 \%)$ \\
$25-36$ & $1(8,3 \%)$ & $1(8,3 \%)$ \\
$37-48$ & $2(16,7 \%)$ & 0 \\
Status gizi & & $1(8,3 \%)$ \\
Kurang & $1(8,3 \%)$ & $7(58,3 \%)$ \\
Normal & $6(50 \%)$ & $4(33,3 \%)$ \\
Lebih & $5(41,7 \%)$ &
\end{tabular}

Tabel 2

Pengaruh Pemberian Probiotik terhadap Kadar Kalsium Darah

\begin{tabular}{lccc}
\hline \multicolumn{1}{c}{ Variabel } & $\begin{array}{c}\text { Kelompok } \\
\text { perlakuan }\end{array}$ & $\begin{array}{c}\text { Kelompok } \\
\text { kontrol }\end{array}$ & \multirow{2}{*}{$p$} \\
\cline { 2 - 3 } & Rerata \pm SD & Rerata \pm SD & \\
\hline Kadar kalsium & & & \\
- Sebelum perlakuan & $8,9 \pm 0,8$ & $9,3 \pm 1,3$ & \\
- Setelah 3 minggu & $9,8 \pm 1,6$ & $10,0 \pm 1,8$ & $0,50^{\mathrm{b}}$ \\
- Rata-rata kadar kalsium & $0,9 \pm 1,3$ & $0,7 \pm 1,7$ & $0,88^{\mathrm{b}}$ \\
(g/dl) & $\mathbf{p}=\mathbf{0 , 0 2 ^ { \mathrm { a } }}$ & $\mathrm{p}=0,11^{\mathrm{d}}$ & $0,21^{\mathrm{b}}$ \\
& & &
\end{tabular}




\section{Perubahan Parameter Kadar Kalsium Darah}

Berdasarkan Tabel 2 di atas menunjukkan rata-rata perubahan kadar kalsium responden pada kelompok perlakuan $0,9 \mathrm{~g} / \mathrm{dl}$ dan pada kelompok kontrol 0,7 g/dl. Hasil analisis statistik menunjukkan kenaikan kadar kalsium secara signifikan pada kelompok perlakuan $(p=0,02)$. Namun kenaikan ini tidak memberikan perbedaan yang nyata antara 2 kelompok. Responden yang mendapat perlakuan mengalami kenaikan kadar kalsium yang signifikan dibandingkan dengan kelompok kontrol.

\section{BAHASAN}

Subjek yang mendapat perlakuan mengalami kenaikan kadar kalsium yang signifikan dibandingkan dengan kelompok kontrol. Hasil penelitian ini sejalan dengan penelitian Mishra (2016) yang dilakukan pada pasien PGK yang diberikan kapsul probiotik dengan jenis bakteri yang berbeda (mengandung Bifidobacteria longum $2 \times 10^{9}$ ditambah $0.11 \mathrm{~g}$ oligosakarida) selama 3-4 minggu menunjukan peningkatan serum kalsium dari $5,8 \mathrm{mg} / \mathrm{dL}$ menjadi $9.7 \mathrm{mg} / \mathrm{dL}$. Peningkatan kadar kalsium darah pada penelitian ini akibat menurunnya $\mathrm{pH}$ dalam lumen usus sehingga meningkatkan ionisasi kalsium. ${ }^{8}$

Pada pasien PGK terminal terjadi penurunan aktivasi Vitamin D sehingga kalsium tidak dapat diabsorbsi dari makanan dan jumlah serum akan menurun. Kalsium yang dimakan hanya sekitar $10 \%$ yang diabsorbsi dari traktus intestinalis dan sisanya di ekskresikan dalam feses. Dalam kondisi tertentu, ekskresi kalsium feses dapat melebihi kalsium yang dicerna karena kalsium juga dapat diekskresi kedalam lumen usus. Oleh karena itu, traktus gastrointestinal dan mekanisme regulasi yang mempengaruhi absrobsi dan sekresi kalsium intestinal berperan penting dalam homeostasis kalsium. ${ }^{20,21}$ Pemberian probiotik Lactobacillus juga mampu meningkatkan penyerapan zat gizi, sebagai akibat dari efek perbaikan terhadap mikroflora saluran pencernaan. Fermentasi makanan dalam saluran perncernaan oleh probiotik Lactobacillus akan meningkatkan terbentuknya asam lemak rantai pendek dan menurunkan $\mathrm{pH}$ saluran pencernaan yang akan membebaskan mineral yang terikat dalam ikatan matriks makanan kaya phytat dan bioavailabilitas mineral seperti kalsium sehingga akan meningkat. Selain itu, menurunkan gejala flatulensi dan diare akibat pemberian antibiotik, sehingga memberikan manfaat bagi kesehatan usus. ${ }^{22}$ Ranganathan et al (2013) menyatakan terapi pendamping yang diberikan pada pasien PGK terminal dengan suplemen yang mengandung probiotik dapat mengembalikan keseimbangan antara bakteri non patogen dan bakteri patogen sehingga penyerapan zat gizi dapat optimal. ${ }^{15}$

Hasil penelitian ini juga menunjukan bukti bahwa pemberian probiotik Lactobacillus meningkatkan kadar kalsium darah. Pengobatan standar pada pasien PGK terminal dengan diberikan kalsium karbonat juga membantu suatu bakteri Lactobacillus agar dapat menempel pada lumen usus. Secara spesifik, kalsium karbonat juga digunakan sebagai fungsi penurunan asam dan mempertahankan keberadaan probiotik Lactobacillus dalam lumen usus. Pada pasien PGK terminal, pemberian probiotik Lactobacillus dengan meningkatnya kelangsungan hidup bakteri mampu menekan pertumbuhan bakteri patogen karena tahan terhadap keasaman sistem percernaan dan antibiotik yang digunakan untuk pengobatan PGK terminal. ${ }^{23,24}$

Keterbatasan penelitian ini adalah tidak dapat dilakukan monitoring asupan makan setiap hari yang berkaitan dengan tempat tinggal subjek yang kurang terjangkau dan tidak melihat status mikroflora pada usus untuk melihat keefektifan pemberian probiotik terhadap keadaan mikroflora dikarenakan keterbatasan dana dan waktu.

\section{SIMPULAN DAN SARAN}

\section{Simpulan}

Berdasarkan hasil penelitian ini, dapat disimpulkan bahwa ada peningkatan yang signifikan kadar kalsium pada kelompok perlakuan dibandingkan pada kelompok kontrol.

\section{Saran}

Bagi pasien PGK terminal diperlukan penambahan suplemen probiotik karena akan berpengaruh baik terhadap peningkatan kadar kalsium darah pada saat kekurangan kalsium darah atau hipokalsemia. 


\section{UCAPAN TERIMA KASIH}

Kepada Direktur RS Rumah Sehat Terpadu Dompet Dhuafa yang telah memberikan izin untuk penelitian ini dan kepada tim di Unit Hemodialisa yang telah membantu pelaksanaan penelitian ini.

\section{RUJUKAN}

1. Perkumpulan Nefrologi Indonesia. $7^{\text {th }}$ Report of Indonesian Renal Registry. Jakarta; 2014.

2. Suwitra, K. Penyakit Ginjal Kronik, Di dalam: Sudoyo, A.W.(ed), Buku Ajar IImu Penyakit Dalam, Ed ke-5 Jilid 2. Jakarta: Interna Publishing; 2009.

3. Sukandar, E. Gagal Ginjal dan Panduan Terapi Dialisis. Edisi ke-3, Pusat Informasi IImiah Bagian IImu Penyakit Dalam RS. Dr. Hasan Sadikin, Bandung; 2006.

4. Mann J \& Truswell A.S. Essentials of Human Nutrition.Oxford University Press; 2012.

5. Guyton and Hall. Textbook of Medical Physiology. 12th ed. Elsevier: Singapore; 2011; 432-433.

6. National Kidney Foundation. About Cronic Kidney Disease. The National Kidney Foundation, New York. 2015. Available from: https://www.kidney.org/kidneydisease/aboutckd. 2016.

7. National Kidney Foundation. K/DOQI clinical pratice guidelines for bone metabolism and disease in chronic kidney disease. AM J Kidney Dis. 2003; 42 ( 4 Suppl 3): S1-201.

8. Mishra, Seema. Bifidobacteria longumProbiotic therapy for the treatment of hyperphosphatemia in end stage renal disease patient. International Journal of Applied Research. 2016; 2(3): 97-98.

9. Widiyaningsih, EN. Peran Probiotik Untuk Kesehatan. Jurnal Kesehatan. 2011; 4 (1): 1420

10. Lacidofil ${ }^{\mathrm{TM}}$.From http://www.medicastore.com. (diakses Agustus 15 2016).

11. Foster LM, Thomskin TA, Gahl WJ. A comprehensive post-market review of studies on a probiotic containing Lactobasicilluc helveticcus R0052 and Lactobacillus rhamnosus R0011. Benefecial Microbes. 2011; 4: 319-334.

12. lactobacillusrhamnosus.http://www.probiotic.org.(diakses oktober 202016 )

13. Indrayanto $\mathrm{Y}$, Prasetyo DH. Efek Probiotik terhadap Mortalitas, Derajat Inflamasi Intestinal, dan Kadar IgA pada Mencit Model Sepsis. MKB. 2013; 45:10-15.
14. Foster LM, Thomskin TA, Gahl WJ. A comprehensive post-market review of studies on a probiotic containing Lactobasicilluc helveticcus R0052 and Lactobacillus rhamnosus R0011. Benefecial Microbes. 2011; 4: 319-334.

15. Ranganathan N, Pechenyak $B$, Vyas $U$, Ranganathan P, DeLoach S, Falkner B, et al. Dose Escalation, Safety and Impact of a StrainSpecific Probiotic (Renadyl ${ }^{\mathrm{TM}}$ ) on Stages III and IV Chronic Kidney Disease Patients. J Nephrol Ther. 2013; 3: 1-9.

16. Simadibrata, Marcellus, Suzanna Ndraha, Robert Tedjasaputra, Ari Fahrial Syam, et al. Revealing the effect of probiotic combination: Lactobacillus rhamnosus and Lactobacillus acidophilus (Lacidofil ${ }^{\circledR}$ ) on acute diarrhea in adult patients. Journal of Clinical Medicine and Research. 2013; 5(2): 23-28.

17. Abaturov A. Administration of Probiotics Containing Strains Lactobacillus rhamnosus and Lactobacillus acidophilus to Improve the Efficiency of Helicobacter Pylori Eradication in Children. International Scientific Conference on Probiotics and Prebiotics. 2015.

18. Dexa Medica. Lacidofil. Jurnal Kedokteran dan Farmasi. 2007; 10 (1).3-7.

19. Foster, L.M., T.A. Tompkins, and W.J. Dahl. A comprehensive post-market review of studies on a probiotic product containing Lactobacillus helveticus R0052 and Lactobacillus rhamnosus R0011. Beneficial Microbes, 2011; 2(4): 319334.

20. National Kidney Foundation. K/DOQI clinical pratice guidelines for bone metabolism and disease in chronic kidney disease: serum calsium and calsium-phosphorus product. AM J Kidney Dis. 2003; 42 ( 4 Suppl 3): S1-201.

21. Berdanier CD, Zempleni J. Advanced Nutrition; Macronutrient, Micronutrient and Metabolism. CRC Press; Taylor \& Francis Group; 2009.

22. Cerbo Alesandro Di, Pezzuto Federica, Palmieri Lucia, Rottigni Valentina, Lannitti Tommaso. Clinical and experimental use of probiotic formulation for management of endstage renal disease: An update. International Urology and Nephrology. 2013; 45(6):123.

23. Kirboga $S$ \& Oner $M$. Application of experimental design fo the precipitation of calcium carbonate in the presence of biopolymer. Powder Technology.2013; 249. 95104.

24. Culpepper Tr, Coppola JA, Lopez D, Rohani A, Mai-Volker, Dahl W. The effect of calcium supplementation on gastrointestinal survival of Lactobacillus spp. University of Florida, Gainesville, FL. 2013. 